\title{
Investigation of frictional impact on polyester yarn during knitting DOI: 10.35530/IT.072.06.1785
}

ALI AFZAL

SAJID HUSSAIN

ABDUL WAQAR RAJPUT

SYEDA SIDRA BATOOL

HAFSA JAMSHAID

USMAN ALI

\section{ABSTRACT - REZUMAT \\ Investigation of frictional impact on polyester yarn during knitting}

The usage of polyester (PET) in fabrication is increasing day by day due to its properties, ease of physical and chemical modification. The aim of this work is to understand the effect of temperature on Polyester (PET) during knitting. For checking the rise of temperature Infrared (IR) camera is used. Microscopic images are used for studying the effect of temperature on fibre/yarn structure. Morphological analysis is also done by X-ray diffraction (XRD) which shows disturbance of polymeric chains, causing change in crystal size due to elevated temperature. The beads formation and filament breakage are clearly seen in images. Due to this knitting fault, shade variation after dyeing occurred. It is concluded that structural morphology of polyester yarn changes due to friction of yarn with knitting machine parts. Fabric appearance and fabric quality also disturbed which leads to rejections and high losses.

Keywords: polyester (PET), weft knitting, friction, structure and properties

\section{Analiza impactului de frecare asupra firului de poliester în timpul tricotării}

Utilizarea poliesterului (PET) în fabricație crește pe zi ce trece datorită proprietăților sale și modificărilor fizice și chimice. Scopul acestei lucrări este de a înțelege influența temperaturii asupra poliesterului (PET) în timpul tricotării. Pentru verificarea creșterii temperaturii se folosește o cameră cu infraroșu (IR). Imaginile microscopice sunt folosite pentru studiul influenței temperaturii asupra structurii fibrei/firului. Analiza morfologică se efectuează și prin difracție de raze $X$ $(X R D)$, care arată perturbarea lanțurilor polimerice, determinând modificarea dimensiunii zonei cristaline din cauza temperaturii ridicate. Formarea efectului de perlare și ruperea filamentului se observă clar în imagini. Din cauza acestui defect de tricotare, a apărut o variație de nuanță după vopsire. Se ajunge la concluzia că morfologia structurală a firului de poliester se modifică datorită frecării firului cu piesele mașinii de tricotat. De asemenea, aspectul și calitatea tricotului sunt perturbate, ceea ce duce la respingeri și pierderi mari.

Cuvinte-cheie: poliester (PET), tricot din bătătură, frecare, structură și proprietăți

\section{INTRODUCTION}

Polymers can be natural or synthetic depending on their origin i.e., natural or synthetic $[1,2]$. Depending on the form and use of polymers can be classified as plastics, elastomers, fibre or liquid resin [3-4]. Polymers have different mechanical \& thermal properties according to their nature [5-6]. If these polymers are drawn into long lengths, whose length is 100 times more than its diameter, polymers are called fibre [7]. Some typical examples of these polymers are Polyesters, Nylon, polypropylene etc. These fibres are extensively used in textile sector and other industries and their potential use is increasing rapidly. Polyester (PET) fibres take a leading position among all chemical fibres. Poly(ethylene terephthalate) (PET) is the predominant polyester used for fibre production, not only because of its good enduse properties and economy of production but in particular because of the ease of physical and chemical modification, suppressing negative and enhancing positive properties of PET fibre has become very successful in the conventional as well as in fashion industry due to its chemical resistance, wrinkle resistance and its quick-drying properties. The unique properties of these fibres are due to the presence of aliphatic and aromatic parts in macromolecular chains and the regular molecular structure [8]. PET has much demand over all other synthetic fibres. PET (filament and staple) makes up to $95 \%+$ of future global synthetic fibre production growth [9]. Due to durability and less in cost it is used in many fabrication techniques. Knitting is the 2nd largest technique of fabric formation after weaving and has its charms due to comfort and flexibility. Knitted garments have vast application in causal, sports and formal wear.

Thermal damage is one of the most frequent causes of complaints about synthetic fibres. It leads many problems like yellowing, loss of strength, uneven fabric appearance (light reflection) and dyeing behaviour (spots, streaks etc.). Thermal damage can occur due to different process like singing, pressing etc. Another form of thermal damage is the thermal deformation due to heat of friction, which can occur during friction, 
impact, striking, cutting or punching out during textile production and garment manufacture. Heat due to friction/abrasion is the deterioration of textiles when in contact with another surface. Friction ultimately produces the heat, results in the lowering the performance characteristics e.g., strength, along with it also affects the surface look of the fabric [9-16]. Mahall has shown many typical examples of this [17]. Buchanan and Hardegree [18] described the influence of heat and tension (for example, during drawing, texturizing and occasionally dyeing) on faults in yarns made of polyester, nylon 6.6 and polypropylene. Nanal [19] investigated the damage due to excessive heat and mechanical effects.

The purpose of this research is to study the effect of heat due to frictional contact of knitting machine parts, on morphology of PET by showing good qualitative picture on the influence of structural changes in dyeing. Although other researchers also mentioned that due to excessive heat, structural differences occurred in the PET in woven fabric, but there is little or no study about the effect of heat on PET filament yarn during knitting.

\section{EXPERIMENTAL WORK}

\section{Materials and method}

The $100 \%$ PET intermingled yarn was used in two linear densities 100 denier and 150 denier for knitting. Intermingled yarn has filaments with binding points in its length and slightly twisted. Samples were produced on double jersey (Rib) and single jersey circular knitting machine of 30" diameter. Samples were produced of stich length $0.275 \mathrm{~cm}$ at a speed of $20 \mathrm{rpm}$. Total 4 samples were prepared. All the physical properties of samples were measured according to standards. Samples notations were made by software Degimizer in table 1.

\section{Testing}

To observe that either temperature was increased or not IR camera was used. Real time measurement was done by IR camera on knitting machines Infrared (IR) camera, IR-916, Cantronic systems, Canada. The most important methods of investigation for thermal damage are microscopy, dyeing tests and thermal analysis [20].
Microscopic analysis/study

Microscopy is usually the initial method of characterizing the textiles. Microscopic Mc 50(slides), 1280 (fabric) Micros, Austria 1000, magnification was used to analyse the fibre surface. Samples were taken after 5 minutes (min.) and 100 minute (min.) of machine working for both types of structures. Samples were prepared according to the size of glass slides and examined according to ASTM E2228.

Morphology

For more detailed examination of particular components can be performed with techniques such as transmission and reflectance microscopy. X-Ray diffraction $(X R D)$ is used to study the structure /morphology of materials. XRD analysis was applied using a PANalytical X'Pert Pro MPD, Netherland powered by a Philips PW3040/60 X-ray generator and fitted with an X'Celerator detector. Diffraction data is acquired by exposing powder samples to $\mathrm{Cu}$-Ka X-ray radiation, $\mathrm{X}$-rays were generated from a $\mathrm{Cu}$ anode supplied with $40 \mathrm{kV}$ and a current of $40 \mathrm{~mA}$. The equatorial diffraction patterns $(2 \theta)$ were recorded from 10 to 40. Intensity (I) calculated, I observed are drawn and their relation is expressed in the figures. The XRD analysis is taken according to XRD ASTM D3906. For this analysis the samples were taken for each type, one at initial stage i.e., $5 \mathrm{~min}$ and other sample at the elevated temperature of machine i.e., $100 \mathrm{~min}$. and comparative analysis was done.

\section{Dyeing test}

Dye test was also performed of all samples, to check the dye shade variation of samples. High temperature dying machine HD -12E, TSUJI, Japan was used. For this Disperse dye was used. The temperature of dying was $130^{\circ} \mathrm{C} .1 \mathrm{~g}$ dispersing agent is used Acetic acid was added to control $\mathrm{pH}$ of the solution. The samples were dyed up to 45 minutes.

\section{RESULTS AND DISCUSSIONS}

\section{Effect of temperature on polyester yarn}

The relationship between heat generated verses time for single jersey machine and Rib machine are given in figures 1 and 2 respectively. Variation in temperature with time of the needle is given for single jersey machine (figure 1,a) and rib machine (figure 2,a).

\begin{tabular}{|c|c|c|c|c|c|}
\hline \multicolumn{6}{|c|}{ SAMPLE NOTATION } \\
\hline \multirow{2}{*}{$\begin{array}{c}\text { Sample } \\
\text { description }\end{array}$} & \multicolumn{4}{|c|}{ Machine settings } & \multirow{2}{*}{ Notation } \\
\hline & \multicolumn{2}{|c|}{ Track } & Feeder 1 & Feeder 2 & \\
\hline \multirow{2}{*}{ Single jersey } & \multirow{2}{*}{ Cylinder } & 1 & $\mathrm{~K}$ & $\mathrm{~K}$ & \\
\hline & & 2 & $\mathrm{~K}$ & $\mathrm{~K}$ & \\
\hline \multirow{4}{*}{$1 \times 1$ rib } & \multirow{2}{*}{ Dial } & 1 & $\mathrm{~K}$ & $\mathrm{~K}$ & \\
\hline & & 2 & $\mathrm{~K}$ & K & \\
\hline & \multirow{2}{*}{ Cylinder } & 1 & $\mathrm{~K}$ & $\mathrm{~K}$ & \\
\hline & & 2 & $\mathrm{~K}$ & $\mathrm{~K}$ & \\
\hline
\end{tabular}


While figure $1, b$ and figure $2, b$ show the change in temperature with time of cam box for single jersey and rib machine respectively. In weft knitting, due to frictional contact of yarn with different mechanical parts such as tensioners, feeders, guides, sinkers and needles, generates heat which leads to increase the temperature of the parts The temperature of needle and cam was measured through IR camera after every 10 minutes intervals from 0 to 100 minutes working range, as needle and cam have direct frictional contact, which increase their temperature. The needle as well as cam box showed the same trend for rise in temperature verses time however the value of temperature was different. The elevation in temperature with time was higher for needle as compared to the cam box since the yarn was in direct frictional contact with needle which ultimately increases temperature of needle. However, cam box isn't in contact with yarn, so it heats up indirectly by the transference of heat from needle by the process of conduction and convection. That's why temperature elevation was found more in needle than cam box.

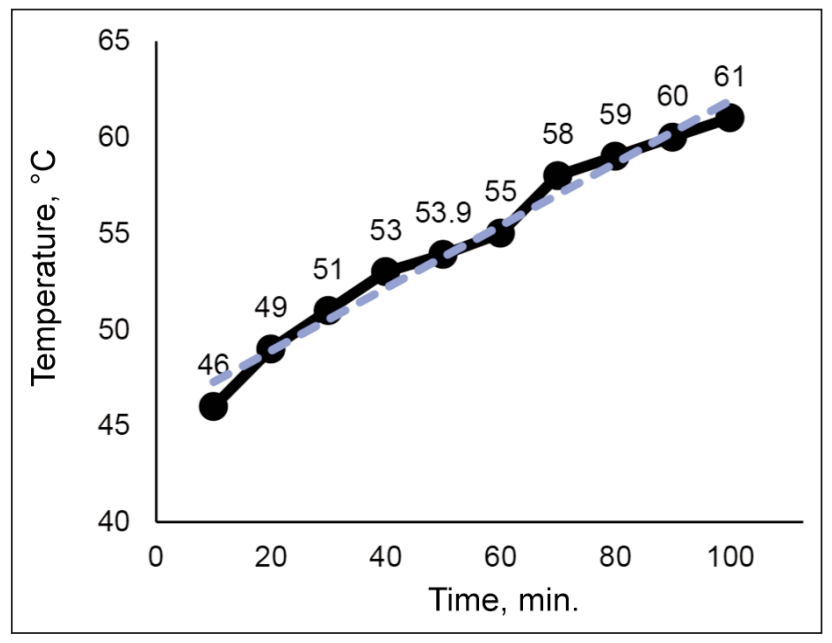

a

\section{Surface analysis}

The effect of machine heat on the polyester yarn surface was analysed with Microscope which helps to determine the changes in yarn morphology. The microscopic images of yarn surface of single jersey fabric with 100 denier and 150 denier are shown in figure 3 . The effect of machine heat is significant as shown in figure $3, b$ and $d$. Figure $3, a$ is the image of fabric taken after running of machine for 5 minutes which shows normal yarn surface and figure $3, b$ is the image of fabric taken after 100 minutes of machine start-up which shows filament breakages, bead formation and disturbance of filaments. Fabric made with 150 denier yarn has less effect of heat as compared to the 100-denier yarn as shown in figure 3, c and $d$. Same effect was analysed in the fabric surface made on Rib machine as shown in figure 4 fabricated with 100 denier and 150 denier filaments respectively.

The results depicted that the polyester yarn was normal without any observable change after 5 minutes of operation, whereas, when machine runs for 100 minutes, beads were formed on the surface of the yarn. The reason might be lies in frictional contact of the yarn with metallic machine parts at high speed of

Fig. 1. Effect of running time on Needle \& Cam box heat generation for Single jersey Machine: $a-$ relation between running time and heat generated by needle; $b$ - relation between running time and heat generated by cam box

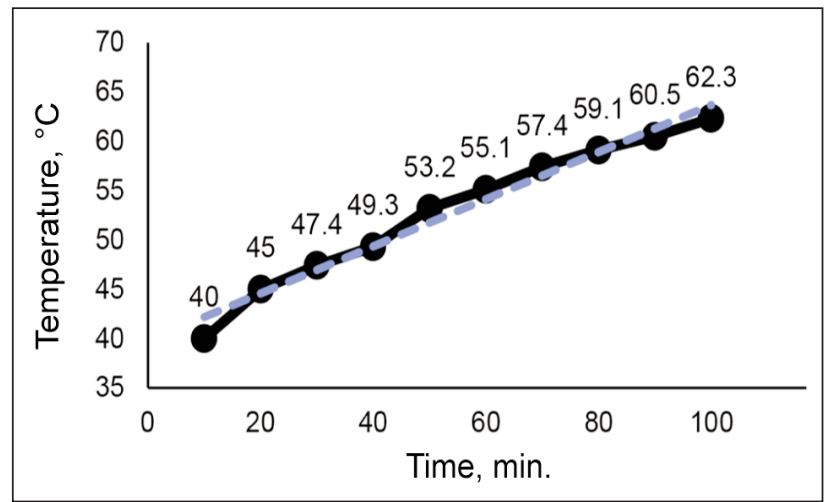

a

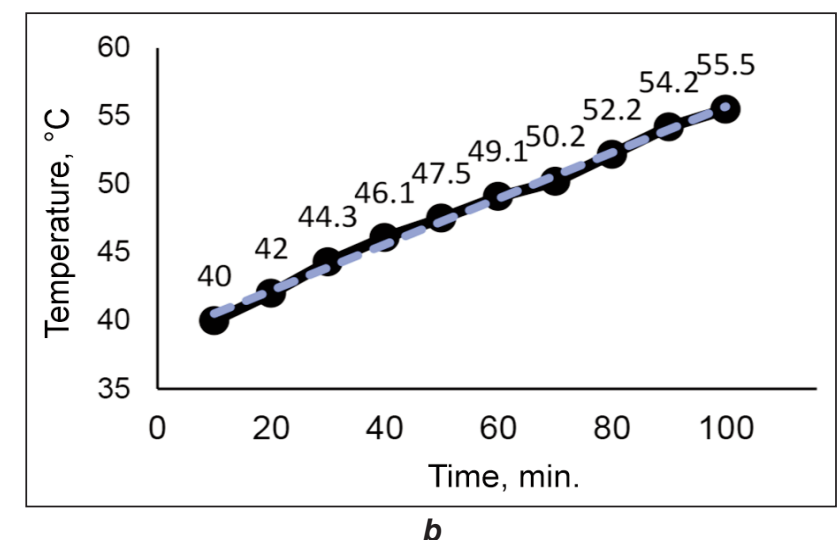

Fig. 2. Effect of running time on Needle \& Cam box heat generation for Rib Machine: $a$ - relation between running time and heat generated by needle; $b$ - relation between running time and heat generated by cam box 

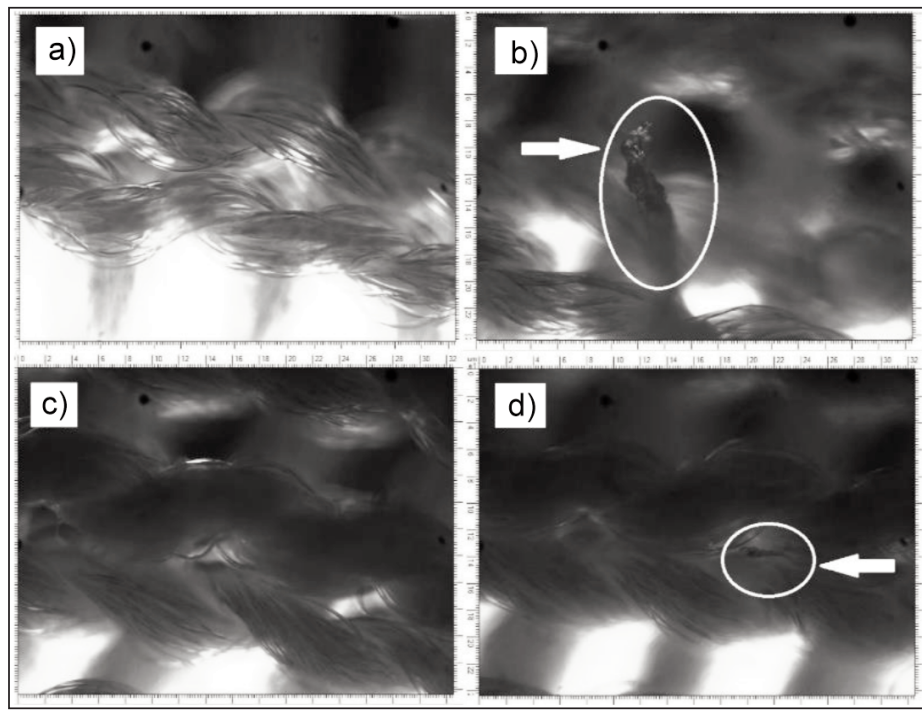

Fig. 3. Microscopic images of single jersey fabrics developed with different deniers at different time of operations, $a$ - filament 100 denier at 5 minutes; $b$ - filament 100 denier at 100 minutes; $c$ - filament 150 denier at 5 minutes; $d$-filament 150 Denier at 100 minutes
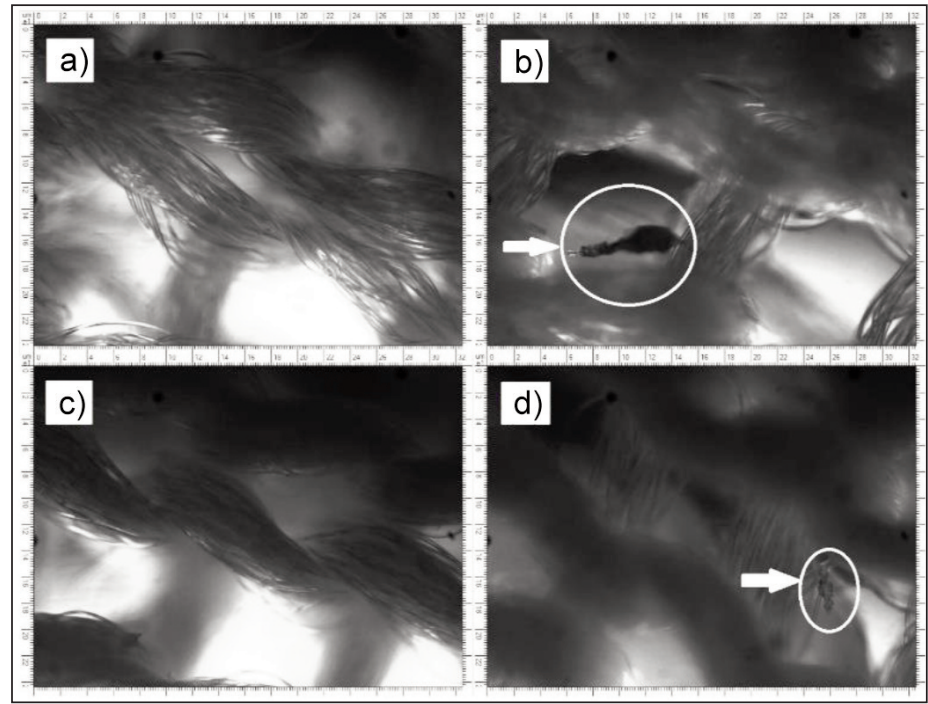

Fig. 4. Microscopic images of rib fabrics developed with different deniers at different time of operations: $a$ - filament 100 denier at 5 minutes; $b$ - filament 100 denier at 100 minutes; $c$ - filament 150 denier at 5 minutes; $d$ - filament 150 denier at 100 minutes fabrics fabricated with 100 denier at different operating hours are shown in figure 5.

The general shape of obtained diffractogram agrees with the literature reported diffractograms of partially crystalline polyester fibres. The peaks were obtained at 2thetha position of $17.7^{\circ}, 22.8^{\circ}$ and $25.8^{\circ}$. The obtained peaks were characteristics reflections of (100), (010) and $(1 \overline{1} 0)$ crystal plane. The correspond-ing side spacing for obtained peaks were $4.98 \mathrm{~A}$, $3.89 \mathrm{~A}$ and $3.45 \mathrm{~A}$ respectively. The obtained results suggested that the basic crystal structure of all fabric samples is triclinic. It is hence concluded that influence of heat generated during knitting process to which polyester yarn was subjected did not influenced the crystalline structure of polymer.

The peaks obtained at different operating hours were at same position with small change in peak height. The change in peak height changes the full width of peak at mid value of maximum peak height (FWMMPH) for samples at different operating hours. These results suggested small change in crystal size at different operating hours. The elevated temperature of machine parts due to frictional contact of PET yarn at high speed cause calendaring like effect. This result may also be caused due to damage of filaments by heated frictional contact with knitting machine parts. With the increase in temperature, the polymeric chains were heat treated with temperature gradient across the fibre diameter. In general, short exposure of heat treatment do not influence significantly on crystallinity but here abrasion effect on the fibre enhances and promotes skin treatment of fibre.

\section{Dyeing test}

Dyeing test was performed to investigate the changes in dyeing behaviour after frictional contact. Figure 6 (100 denier) and figure 7 (150 denier) show the images of single jersey dyed fabric after 5 minutes and 100 minutes operation which causes friction and machine gets heated. When yarn passes through these heated parts, heat may transfer to the filaments which are on the surface of the yarn and beads are formed due to the melting at specific points.

\section{XRD analysis}

$\mathrm{XRD}$ analysis was performed to determine the changes in thermal characteristics of the PET filament. The XRD analysis was done to check the effect of temperature on polymeric chains i.e., any modification in crystalline region of polymer. The diffractograms of single jersey and rib samples showed similar shapes. The typical diffractograms obtained for single jersey

industuria textillă

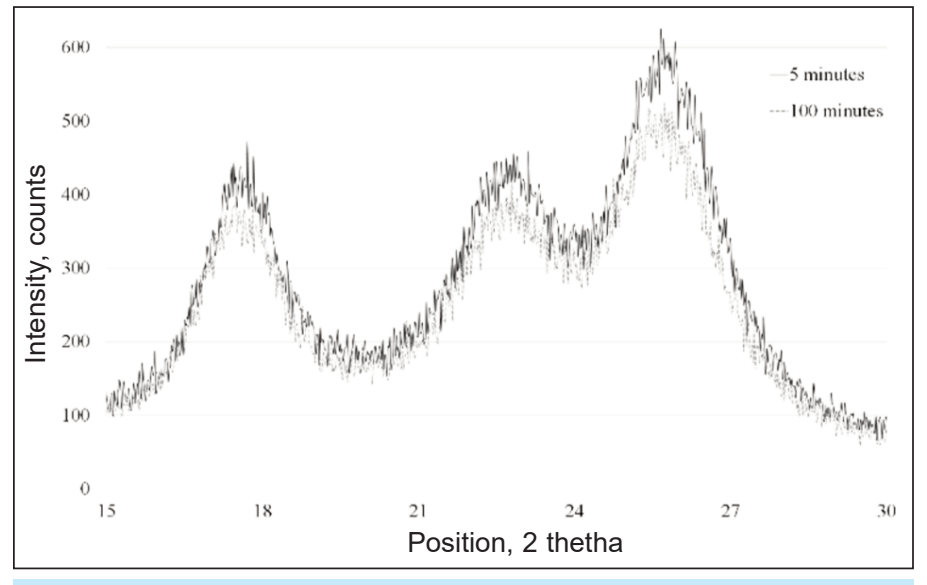

Fig. 5. X-Ray diffraction patterns of single jersey fabric samples at different operating hours 


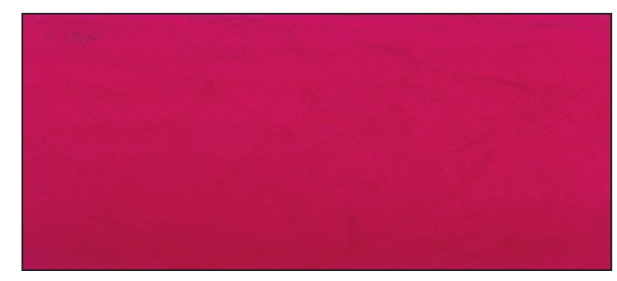

a

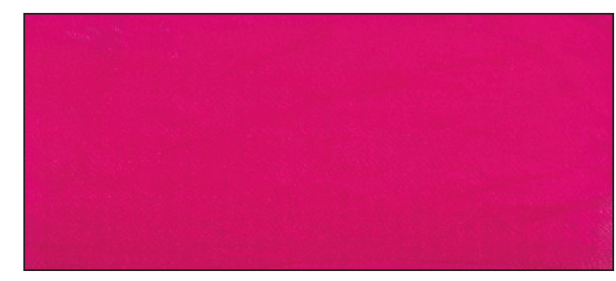

$\boldsymbol{b}$

Fig. 6. Dyed single jersey knitted sample of 100 denier: a - after 5 minutes running of machine; $b$ - after 100 minutes running machine

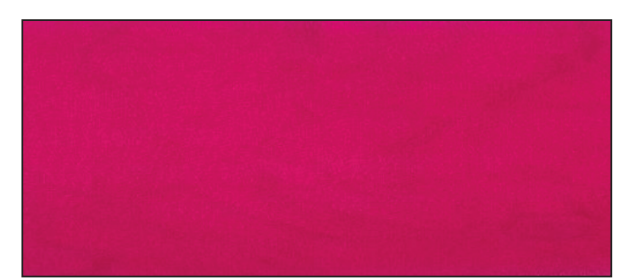

a

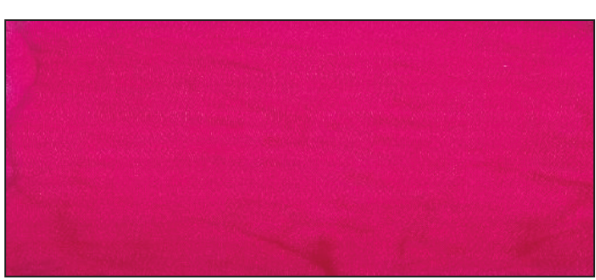

b

Fig. 7. Dyed single Jersey knitted sample of 150 denier: a - after 5 minutes of running machine; $b$ - after 100 minutes of running machine

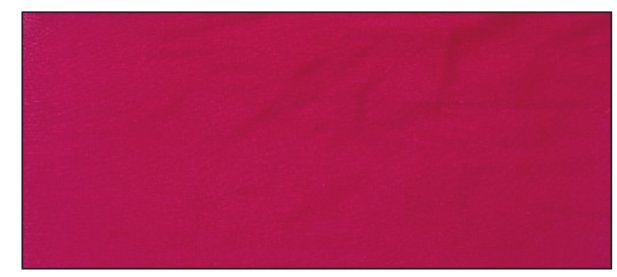

a

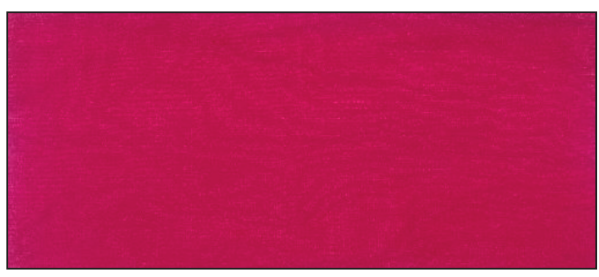

$\boldsymbol{b}$

Fig. 8. Dyed Rib knitted sample of 100 denier: $a$ - after 5 minutes running of machine; $b$ - after 100 minutes running of machine

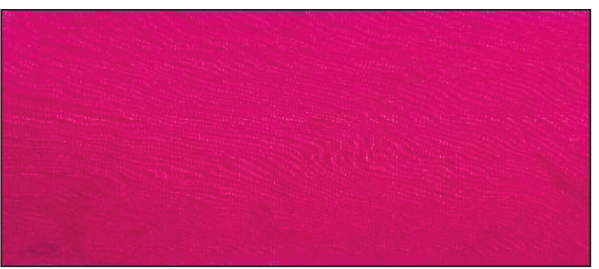

a

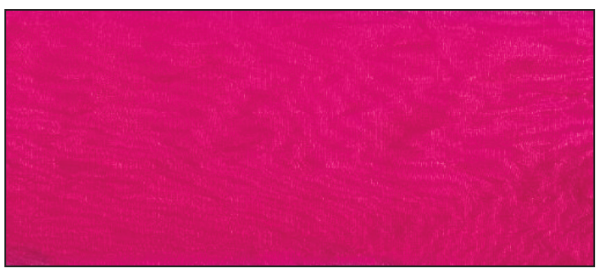

b

Fig. 9. Dyed Rib Knitted sample of 150 denier: $a$ - after 5 minutes running of machine; $b$ - after 100 minutes running of machine

respectively. A significant change in shade of the dyed fabric was observed between different operating hour samples. The fabric sample taken after 5 minutes (figure $8, a$ ) of machine operation shows darker shade as compare to the fabric taken after 100 minutes figure $8, b$ of machine operation. The same change in shade was observed for rib dyed fabric as shown in figure 9 and figure 10 fabricated with 100 denier and 150 denier respectively. The change in dye shade is might be due to change in surface morphology.

\section{CONCLUSION}

In this study the effect of frictional contact on PET filament during knitting process was observed. The results concluded that use of PET filament yarn in knitting machine causes problems to the quality of fabric produced. When the polyester yarn passes from the heated parts, it directly affects its surface morphology. This distorts the appearance of developed fabric and significantly changes the surface reflections which is also prominent in dye take up i.e., shade variation in fabric after dyeing. The results suggested installation of heat dissipating systems on the knitting machines which are working in continuous operation mode using thermally resistive polymer yarns to avoid change in surface appearance. This effect is more prominent in summer due to elevated temperature of knitting production floor.

\section{ACKNOWLEDGEMENT}

The authors would like to thank, Muhammad Rizwan \& Hazrat Habib for cooperation in this work. 


\title{
REFERENCES
}

[1] Allen, G., Bevington, J.C., Comprehensive Polymer Science: 2nd Supplements, Oxford: Pergamon Press,1996

[2] Ebewele, R.O., Polymer Science and Technology: $1^{\text {st }}$ ed., CRC Press, 2000

[3] Varadan, V.K., Vinoy, K.J., Gopalakrishnan, S., Smart Material Systems and MEMS: Design and Development Methodologies, John Wiley \& Sons Ltd., 2006

[4] Gowariker, V.R., Viswanathan, N.V., Sreedhar, J., Polymer Science, New York: John Wiley \& Sons Inc., 1986

[5] Miller, R.W., Murayama, T., Dynamic mechanical properties of partially oriented polyester (POY) and draw $\square$ textured polyester (PTY) yarns, In: J. Applied. Polymer Sciences, 1984, 29, 933-939

[6] Carbone, P., Rapallo, A., Ragazzi, M., Tritto, I., Ferro, D.R., Glass Transition Temperature and Chain Flexibility of Ethylene-Norbornene Copolymers from Molecular Dynamics Simulations, In: Macromolecular Theory \& Simulations, 2006, 15, 457-468

[7] Orchin, M., Macomber, R.S., Pinhas, A.R., Wilson, R., The Vocabulary and Concepts of Organic Chemistry: $2^{\text {nd }}$ ed., John Wiley \& Sons Inc., 2005

[8] Militky, J., Handbook of Properties of Textile and Technical Fibres: $2^{\text {nd }}$ ed., Cambridge: Woodhead Publishing Ltd., 2018

[9] Qin, M.Y., Global Fibres Overview: Synth. Fibres Raw Mater. Comm. Meet., APIC., 2014

[10] Collier, B.J., Epps, H., Textile Testing and Analysis, Englewood Cliffs, New Jersey: Prentice-Hall, 1998

[11] Manich, A.M., Castellar, M.D., Sauri, R.M., Abrasion Kinetics of Wool and Blended Fabrics, In: Textile Research Journal, 2001, 71, 6, 469-474

[12] Alpay, H.R., Becerir, B., Akgun, M., Assessment of Reflectance and Color Differences of Wool Fabrics after Abrasion, In: Textile Research Journal, 2005, 75, 8, 607-615

[13] Alpay, H.R., Becerir, B., Akgun, M., Assessment of Reflectance and Color Differences at Cotton Fabrics after Abrasion, In: Textile Research Journal, 2005, 75, 4, 357-361

[14] Akgun, M., Becerir, B., Alpay, H.R., Abrasion of polyester fabrics containing staple weft yarns: Color strength and color difference values, In: AATCC. Rev, 2006, 6, 3, 40-43

[15] Kaplan, S., Karaman, C., Skin-Fabric Friction and Other Performance Characteristics of Socks Fabrics Produced from Cellulosic Fibers, In: Tekstil ve konfeksiyon, 2018, 28, 3, 213-220

[16] Tiritoğlu, M., Kavuşturan, Y., Investigation Of Abrasion Resistance and Bursting Strength of Warp Knitted Raschel Fabrics, In: Tekstil ve konfeksiyon, 2017, 27, 2, 182-190

[17] Mahall, K., Quality Assessment of Textiles - Damage Detection by Microscopy: 2nd ed, Berlin: Springer, Verlag, 2003

[18] Buchanan, D.R., Hardegree G.L., Thermal Stress Analysis of Textile Yarns, In: Textile Research Journal, 1977, 47, 11, 732-740

[19] Nanal, S.Y., Problems occurring in manufacture of polyester staple fibre, In: Journal of the Textile Associations, 2001, 62, 49-52

[20] Houck, M.M., Identification of Textile Fibers, Cambridge: Woodhead Publishing Ltd., 2009

\author{
Authors: \\ ALI AFZAL ${ }^{1}$, ABDUL WAQAR RAJPUT ${ }^{2}$, HAFSA JAMSHAID ${ }^{1}$, SAJID HUSSAIN³, \\ SYEDA SIDRA BATOOL ${ }^{4}$, USMAN ALI ${ }^{2}$ \\ ${ }^{1}$ Protective Textile Research Group, Faculty of Textile Engineering, National Textile University, Pakistan \\ e-mail:_aliafzalch89@gmail.com, hafsa@ntu.edu.pk \\ ${ }^{2}$ Technical Textile Research Group, BZU College of Textile Engineering, Multan, Pakistan \\ e-mail: usman.ali@bzu.edu.pk \\ ${ }^{3}$ Department of Clothing, Technical University of Liberec, Czech Republic \\ e-mail: sajid.hussain@umt.edu.pk \\ ${ }^{4}$ School of Textile and Design, University of Management and Technology, Lahore, Pakistan \\ e-mail: sidra.batool@umt.edu.pk \\ Corresponding author: \\ ABDUL WAQAR RAJPUT \\ e-mail: waqar.rajput@bzu.edu.pk
}

